\title{
LEITURA E CONSCIENTIZAÇÃO DAS EXPRESSÕES ESTEREOTIPADAS
}

\section{Márcio Balbinot}

\section{INTRODUÇÃO}

A leitura é considerada uma das grandes ferramentas para que o aluno domine o vocabulário, a ortografia, o que o ajudaria muito a produzir um bom texto. Mas antes disso, é necessário que o aluno saiba ler, ou seja, que ele descubra qual o sentido que um texto quer lhe passar.

Em vista disso, este artigo tem como objetivo sustentar que as Expressões Estereotipadas (EEs) contribuem para o aluno realizar a leitura de um texto. Supõe-se que o aluno, ao ser conscientizado da presença das EEs nos textos, teria mais facilidade em ler um texto, ou seja, em dar-lhe um sentido. Também serão apresentados conceitos, tais como o de leitura e de Expressões Estereotipadas, para melhor entender a proposta deste artigo.

\section{LEITURA}

O que se entende por leitura? Ler, segundo Lentin (1996, p.118), é uma "atividade de linguagem que permite trabalhar com a significação (e não com o decifrar)". De acordo com essa definição de leitura, "o leitor, portador de esquemas (mentais) socialmente adquiridos, acionaria seus conhecimentos prévios e os confrontaria com os dados do texto, 'construindo', assim, o sentido. Nessa concepção, o bom leitor é aquele que é capaz de percorrer as marcas deixadas pelo autor do texto para chegar à formulação de suas idéias e intenções (Coracini, 1995, p.14).

Geraldi (1999) acrescenta ainda que a leitura é um processo de interlocução entre leitor/autor mediado pelo texto. É um encontro com o autor, ausente, que se dá pela sua palavra escrita. Nesse processo, o leitor é um agente que busca significações. O autor deu uma significação ao seu texto, imaginou seus interlocutores, mas não tem como dominar o processo de leitura de seu leitor. Este, por sua vez, ao realizar a sua leitura, reconstrói o texto, atribuindo-lhe significações.

Na leitura, portanto, "o diálogo do aluno é com o texto. O professor, mera testemunha desse diálogo, é também leitor, e sua leitura é uma das leituras possíveis" (Geraldi,1999, p.92).

\section{EXPRESSÕES ESTEREOTIPADAS}

As Expressões Estereotipadas (ingl. Lexical Phrases) são, conforme Willis (2001), seqüências de palavras que são armazenadas na mente do indivíduo como itens únicos, que podem ser recobrados mentalmente e usados como expressões pré- 
fabricadas, ou seja, expressões já prontas na mente do falante.

Essas expressões são definidas como "estruturas" da língua cuja extensão é variada. Elas são fenômenos lexicais que existem em algum lugar entre os pólos tradicionais do léxico e da sintaxe. São consideradas compostos de forma/função, isto é, apresentam uma forma e desempenham uma função (Nattinger \& De Carrico, 1997).

\section{CONSCIENTIZAÇÃO DAS EXPRESSÕES ESTEREOTIPADAS NA LEITURA}

Entre as atribuições da escola, ressalta-se a de fazer com que o aluno seja competente na leitura. Para que isso ocorra com sucesso, é mister que o aluno seja instruído quanto à recepção de textos, para que ele possa melhorar conscientemente seu desempenho em leitura.

Uma das formas de contribuir para que o aluno desempenhe de forma satisfatória a leitura é a conscientização das EEs. Essas, por serem compostos de forma/função, ajudariam o aluno a construir o sentido do texto. Por exemplo, se num texto aparecesse a seguinte EE "Acredita-se que X", como ela seria lida pelo aluno? Se a ele tivesse sido ensinado o uso das EEs, logo ele iria perceber que "Acredita-se que X" exerce a função de "afirmar" sobre algo. O aluno, então, estaria ciente de que estaria diante de uma afirmação, de uma defesa de um ponto de vista, etc.

É bom ressaltar também que as EEs de um texto nem sempre serão as EEs de outro texto. Isso deve-se à diversa tipologia de textos. A EE "Acredita-se que X" certamente é observada em textos jornalísticos ou de revistas científicas (Superinteressante, Globo Ciência, etc.), mas dificilmente será utilizada na escritura de uma carta entre amigos. Assim, além do aluno estar consciente do uso das EEs, ele teria mais facilidade em identificar um tipo de texto, não cometendo equívocos quanto ao uso de determinadas EEs.

De acordo com Nattinger \& De Carrico (1997), se os estudantes já estão familiarizados com as EEs, então ensiná-las como macro-organizadores no discurso da leitura seria uma segunda fase para alunos mais avançados. Ao invés de eles aprenderem a produzi-las, eles poderiam aprender a reconhecê-las, bem como suas funções correspondentes.

Leitores bem-sucedidos, em suas leituras, tendem a desconsiderar palavras que eles vêem como irrelevantes para o total significado da frase. Por outro lado, leitores mal-sucedidos raramente desconsideram alguma palavra, considerando todas igualmente importantes na contribuição total do significado (Nattinger \& De Carrico, 1997).

Como a concepção de texto e leitura que o aluno tem em relação à língua materna contém muitas semelhanças com a concepção em língua estrangeira, Grigoletto $(1995$, p.86) vem confirmar o que Nattinger e De Carrico defenderam anteriormente sobre o sucesso ou não de um leitor: 
Durante a leitura de um texto em língua estrangeira, os alunos tendem a se apoiar sobremaneira apenas nas palavras conhecidas, que podem ser cognatas ou termos já aprendidos e assimilados, na tentativa de compreensão do texto. A tendência é eleger-se uma hipótese de conteúdo para o texto a partir de uma palavra conhecida ou supostamente familiar e se fixar nessa hipótese mesmo quando ela se revela inadequada.

Pode-se considerar que entre esses termos aprendidos ou assimilados estão as EEs. Através delas, o aluno tentaria construir o sentido do texto. Em língua estrangeira como em língua materna as EEs cumprem um papel importante que é ajudar o aluno a realizar a leitura, associando as EEs com as suas correspondentes funções.

Portanto, os alunos, conscientes da presença das EEs e de suas funções, estariam mais propícios a se tornarem leitores bem-sucedidos. Leitores que seriam capazes de construir o sentido do texto e de percorrer as marcas deixadas pelo autor para chegar à formulação de suas idéias e intenções.

\section{BIBLIOGRAFIA}

CORACCINI, M. J. R. F. Leitura: decodificação, processo discursivo...? In. CORACCINI, M. J. R. F. (Org.). O jogo discursivo na aula de leitura: língua materna e língua estrangeira. Campinas, SP : Pontes, 1995.

GRIGOLETTO, M. A concepção de texto e de leitura do aluno de $1^{\circ}$ e $2^{\circ}$ graus e o desenvolvimento da consciência crítica. In. CORACCINI, M. J. R. F. (Org.). O jogo discursivo na aula de leitura: língua materna e língua estrangeira. Campinas, SP : Pontes, 1995.

LENTIN, L. A dependência do escrito em relação ao oral: parâmetro fundamental da primeira aquisição da linguagem. In. CATACH, N. Para uma teoria da língua escrita. São Paulo : Ática, 1996.

NATTINGER J. R. e DE CARRICO, J. S. Lexical phrases and language teaching. 2nd ed. New York: Oxford University Press, 1997.

WILLIS, J. Lexical phrases - some definitions and examples. Disponível em: <http://www.les.aston.ac.uk/lsu/staff/jrw/research.htm> 